\title{
PENGARUH KEMANDIRIAN BELAJAR DAN KOMPETENSI DOSEN TERHADAP MOTIVASI BELAJAR MAHASISWA (Study Kasus di Program Studi Manajemen UNISLA)
}

\begin{abstract}
the effect of learning independence and lecturers competency towards students' learning motivation (case study at the unisla management study program)
\end{abstract}

\author{
Husen*, Nanto Purnomo** \\ husenmaarif@unisla.ac.id*, nantopurnomo@unisla.ac.id**
}

*) Fakultas Keguruan dan Ilmu Pendidikan, Universitas Islam Lamongan

**) Fakultas Ekonomi, Universitas Islam Lamongan

\section{Abstrak}

Tantangan besar di dunia pendidikan selama pandemi covid 19 adalah mengatasi kesulitan-kesulitan pelaksanaan pembelajaran daring, dan hal yang tak kalah penting adalah membangun dan meningkatkan motivasi belajar mahasiwa di masa pandemi covid 19. Adanya motivasi yang baik dalam belajar akan menunjukan hasil yang baik sehingga di harapkan adanya peningkatan kualitas pembelajaran sebagaimana amanah Undangundang Sistem Pendidikan Nasional Nomor 20 Tahun 2003 pendidikan nasional yang bertujuan untuk mencerdaskan kehidupan bangsa dan peningkatan kualitas penyelenggaraan pembelajaran. Jenis penelitian ini adalah penelitian kuantitatif deskriptif Teknik penentuan sampel menggunakan simple random sampling. Populasi dalam penelitian ini adalah mahasiswa prodi manajemen unisla Teknik Pengumpulan Data menggunakan angket / kuisioner dengan menggunakan skala likert .Alat analisis yang digunakan adalah analisis validitas dan reliabilitas untuk mengetahui kehandalan suatu kuisioner yang digunakan dalam penelitian. Dalam penelitian ini juga menggunakan analisis korelasi, analisis regresi berganda, uji t dan uji $\mathrm{F}$ yang dibantu dengan software IBM SPSS Statistik Versi 25 for windows. Hasil penelitian menunjukkan bahwa variabel kemandirian belajar secara parsial memiliki pengaruh positif dan signifikan terhadap variabel motivasi belajar. Variabel kompetensi dosen secara parsial memiliki pengaruh positif dan signifikan terhadap variabel motivasi belajar. Variabel kemadirian belajar dan kompetensi dosen secara simultan memiliki pengaruh yang signifikan terhadap variabel motivasi belajar mahasiswa. Presentase pengaruh variabel kemandirian belajar dan kompetensi dosen terhadap motivasi belajar mahasiswa menunjukkan nilai $72,2 \%$ dan sisanya seberas $27,8 \%$ dipengaruhi oleh variabel lain selain variabel X1 dan X2.

Keyword : Kemandirian Belajar, Kompetensi Dosen, Motivasi Belajar Mahasiswa

\section{Abstract}

The big challenge in the world of education during the Covid 19 pandemic is overcoming the difficulties of implementing online learning, and what is equally important is building and increasing student motivation during the Covid 19 pandemic. Having good motivation in learning will show good results so that in expect an increase in the quality of learning as mandated by the National Education System Law Number 20 of 2003 national 
education which aims to educate the nation's life and improve the quality of learning. This type of research is descriptive quantitative research. The sampling technique used is simple random sampling. The population in this study were students of Unisla management study program. Data collection techniques used a questionnaire using a Likert scale. The analysis tools used were validity and reliability analysis to determine the reliability of a questionnaire used in the study. In this study also used correlation analysis, multiple regression analysis, $t$ test and F test assisted by the IBM SPSS Statistics version 25 software for windows. The results showed that the learning independence variable partially had a positive and significant effect on the learning motivation variable. The lecturer competence variable partially has a positive and significant effect on the learning motivation variable. The variables of independent learning and lecturer competence simultaneously have a significant influence on student learning motivation variables. The percentage of the influence of the independent learning variable and lecturer competence on student learning motivation shows a value of $72.2 \%$ and the remaining $27.8 \%$ is influenced by variables other than variables $X 1$ and $X 2$.

\section{Keyword: Learning Independence, Lecturer Competence, Student Learning Motivation}

\section{PENDAHULUAN}

Sudah setahun lebih Indonesia telah berusaha mengatasi wabah pandemi covid 19. Berbagai upaya telah dilakukan pemerintah baik daerah dan pusat . mulai dari program Pembatasan Sosial Bersekala Besar (PSBB), Pemberlakuan Pembatasan Kegiatan Masyarakat (PPKM) sejawa dan bali, hingga proses vaksinasi. Salah satu Akan tetapi kegiatan pembelajaran daring dimasa pandemi ini mengakibatkan penurunan tingkat kualitas pendidikan di indonesia. Berdasarkan survei UNICEF pada awal Juni 2020 terhadap 4.016 responden dari 34 provinsi dengan rentang usia 14-24 tahun, 69\% merasa bosan belajar dari rumah (BDR). Selama BDR, responden mengalami dua tantangan utama, yakni 35\% kesulitan akses internet dan $38 \%$ kurang bimbingan guru (https://mediaindonesia.com/). Selain mengatasi kesulitan-kesulitan pelaksanaan pembelajaran daring, hal yang tak kalah penting adalah membangun dan meningkatkan motivasi belajar mahasiwa di masa pandemi covid 19 ini.

Selama Belajar dari rumah mahasiswa dituntut untuk lebih belajar dampak dengan adanya pembatasan sosial akibat pandemi ini adalah penerapan Work From Home ( WFH) dan Kegiatan Belajar dari Rumah secara daring.

Berdasarkan Undang-undang Sistem Pendidikan Nasional Nomor 20 Tahun 2003 pendidikan nasional bertujuan untuk mencerdaskan kehidupan bangsa dan peningkatan kualitas pembelajaran. mandiri. Belajar mandiri berarti belajar secara berinisiatif, dengan ataupun tanpa bantuan orang lain dalam belajar. Adapun keuntungan belajar mandiri bagi siswa salah satunya memberikan kemungkinan untuk maju sesuai pelajaran masingmasing (Miarso,2005). Kemandirian belajar siswa berpengaruh terhadap prestasi belajar maka dari itu perlu dikembangkannya sikap mandiri dalam diri siswa (Siregar,2006). Kemandirian merupakan sebuah bentuk kepercayaan pada diri sendiri untuk mengorganisir, mengembangkan, dan menyelesaikan berbagai masalah dan kesulitan yang dihadapi oleh seseorang. Perilaku mandiri adalah bentuk perilaku yang dapat berdiri sendiri dan tanpa tergantung pada orang lain (Drost,1995) 
Hamalik (2002:36) mengemukakan bahwa proses belajar dan hasil belajar para kurikulumnya, akan tetapi sebagian besar ditentukan oleh kompetensi guru yang mengajar dan membimbing mereka. Menurut undang-undang No 14 Tahun 2005 tentang guru dan dosen, kompetensi guru meliputi: kompetensi pedagogik, kompetensi profesional, kompetensi kepribadian, dan kompetensi sosial.

Wijaya dan Rusyan mengemukakan bahwa guru merupakan faktor yang sangat dominan dan paling penting dalam pendidikan formal pada umumnya karena bagi siswa guru sering dijadikan tokoh teladan, bahkan menjadi tokoh identifikasi diri. Guru dalam tradisi Jawa merupakan akronim dari "digugu lan ditiru" (orang yang dipercaya dan diikuti), bukan hanya bertanggung jawab mengajar mata pelajaran yang menjadi tugasnya, melainkan lebih dari itu juga mendidik moral, etika, integritas, dan karakter. Guru ( Dosen) memiliki peranan yang penting dalam pelaksanaan pembelajaran dan meningkatkan prestasi mahasiswa.

Guru kompeten mampu

\section{METODE}

Jenis penelitian ini adalah penelitian kuantitatif deskriptif yaitu penelitian yang secara sederhana menjelaskan fenomena yang ada dengan menggunakan angka untuk mengelompokkan individu atau kelompok (Suharsaputra, 2012: 42). Teknik penentuan sampel menggunakan simple random sampling. Menurut Sugiyono (2017:82) Teknik simple random sampling adalah teknik yang sederhana karena pengambilan anggota sampel dari populasi dilakukan secara acak tanpa melihat dan memperhatikan kesamaan atau starata yang ada dalam populasi. siswa bukan saatnya ditentukan oleh sekolah, pola, struktur dan isi menciptakan lingkungan belajar yang efektif, menyenangkan, dan mampu mengelola kelasnya, sehingga belajar siswa berada pada tingkat optimal. Sebuah kenyataan yang tidak dapat dimungkiri lagi bahwa kompetensi guru berpengaruh besar terhadap motivasi belajar mahasiswa dan prestasi siswa. Pendapat seorang ahli yang menyebutkan bahwa "motivasi menentukan tingkat berhasil atau gagalnya perbuatan belajar murid. Belajar tanpa adanya motivasi kiranya sulit untuk berhasil" (Hamalik, 2002:61). Hal ini juga sejalan dengan pendapat Sardiman A.M (2014) yang menyatakan bahwa motivasi dapat berfungsi sebagai pendorong usaha dan pencapaian prestasi. Seseorang melakukan suatu karena adanya motivasi. Adanya motivasi yang baik dalam belajar akan menunjukan hasil yang baik. Dari uraian di atas maka peneliti memutuskan untuk meneliti pengaruh Kemandirian Belajar dan Kompetensi Dosen terhadap motivasi belajar mahasiswa (Studi kasus pada mahasiswa Unisla prodi manajemen).

Populasi dalam penelitian ini adalah mahasiswa prodi manajemen unisla. Penelitian ini menggunakan derajat signifikansi $5 \%$. Sampel dalam penelitian ini merupakan mahasiswa aktif prodi manajemen unisla. Teknik Pengumpulan Data menggunakan angket / kuisioner dengan menggunakan skala likert yang dimodifikasi dengan 4 alternatif jawaban. Alternatif jawaban untuk tiap butir beserta skor untuk pernyataan positif (+) dan pernyataan negatif (-) adalah sebagai berikut: 
Tabel 1. Skor angket

\begin{tabular}{|l|c|c|}
\hline \multirow{2}{*}{\multicolumn{1}{|c|}{ Alternatif Jawaban }} & \multicolumn{2}{c|}{ Skor untuk pernyataan } \\
\cline { 2 - 3 } & Positif & Negatif \\
\hline Sangat Setuju/ Selalu & 4 & 1 \\
\hline Setuju/ Sering & 3 & 2 \\
\hline Tidak Setuju/ Jarang & 2 & 3 \\
\hline Sangat Tidak Setuju/ Tidak Pernah & 1 & 4 \\
\hline
\end{tabular}

Alat analisis yang digunakan

adalah analisis validitas dan reliabilitas

untuk

mengetahui kehandalan suatu kuisioner yang digunakan dalam penelitian. Dalam penelitian ini juga menggunakan analisis korelasi, analisis regresi berganda, uji t dan uji $\mathrm{F}$ yang dibantu dengan software IBM SPSS Statistik Versi 25 for windows.

HASIL

\section{Uji Validitas}

Menurut Sunyoto (2013: 142) uji validitas digunakan untuk mengukur valid dan tidaknya suatu kuesioner. Menurut Sugiyono (2009: 188), syarat minimal yang digunakan untuk validitas adalah jika rXY $=0,3$. Jika korelasi antara butir pertanyaan dengan skor total kurang dari 0,3 maka butir instrumen tersebut dikatakan tidak valid. Sebaliknya, jika $r \geq$ 0,3 maka butir instrumen tersebut dikatakan valid.

Tabel 2. Hasil uji validitas variabel Kemandirian Belajar

\begin{tabular}{|l|c|c|l|}
\hline \multicolumn{1}{|c|}{ Butir } & r hitung & r tabel & \multicolumn{1}{c|}{ Ket. } \\
\hline Butir 1 & 0,621 & 0,3 & Valid \\
\hline Butir 2 & 0,436 & 0,3 & Valid \\
\hline Butir 3 & 0,587 & 0,3 & Valid \\
\hline Butir 4 & 0,671 & 0,3 & Valid \\
\hline Butir 5 & 0,668 & 0,3 & Valid \\
\hline Butir 6 & 0,678 & 0,3 & Valid \\
\hline Butir 7 & 0,601 & 0,3 & Valid \\
\hline Butir 8 & 0,62 & 0,3 & Valid \\
\hline Butir 9 & 0,651 & 0,3 & Valid \\
\hline Butir 10 & 0,568 & 0,3 & Valid \\
\hline Butir 11 & 0,597 & 0,3 & Valid \\
\hline Butir 12 & 0,731 & 0,3 & Valid \\
\hline Butir 13 & 0,633 & 0,3 & Valid \\
\hline Butir 14 & 0,658 & 0,3 & Valid \\
\hline Butir 15 & 0,709 & 0,3 & Valid \\
\hline Butir 16 & 0,685 & 0,3 & Valid \\
\hline Butir 17 & 0,616 & 0,3 & Valid \\
\hline Butir 18 & 0,542 & 0,3 & Valid \\
\hline Butir 19 & 0,637 & 0,3 & Valid \\
\hline
\end{tabular}


Tabel 3. Hasil uji validitas variabel Kompetensi Dosen

\begin{tabular}{|l|c|c|l|}
\hline \multicolumn{1}{|c|}{ Butir } & r hitung & r tabel & \multicolumn{1}{c|}{ Ket. } \\
\hline Butir 1 & 0,565 & 0,3 & Valid \\
\hline Butir 2 & 0,652 & 0,3 & Valid \\
\hline Butir 3 & 0,485 & 0,3 & Valid \\
\hline Butir 4 & 0,613 & 0,3 & Valid \\
\hline Butir 5 & 0,717 & 0,3 & Valid \\
\hline Butir 6 & 0,728 & 0,3 & Valid \\
\hline Butir 7 & 0,467 & 0,3 & Valid \\
\hline Butir 8 & 0,64 & 0,3 & Valid \\
\hline Butir 9 & 0,436 & 0,3 & Valid \\
\hline Butir 10 & 0,766 & 0,3 & Valid \\
\hline Butir 11 & 0,815 & 0,3 & Valid \\
\hline Butir 12 & 0,519 & 0,3 & Valid \\
\hline Butir 13 & 0,298 & 0,3 & Valid \\
\hline Butir 14 & 0,84 & 0,3 & Valid \\
\hline Butir 15 & 0,605 & 0,3 & Valid \\
\hline Butir 16 & 0,309 & 0,3 & Valid \\
\hline Butir 17 & 0,562 & 0,3 & Valid \\
\hline Butir 18 & 0,739 & 0,3 & Valid \\
\hline Butir 19 & 0,74 & 0,3 & Valid \\
\hline Butir 20 & 0,671 & 0,3 & Valid \\
\hline
\end{tabular}

Tabel 4. Hasil uji validitas variabel Motivasi Belajar

\begin{tabular}{|l|c|c|l|}
\hline \multicolumn{1}{|c|}{ Butir } & r hitung & r tabel & \multicolumn{1}{c|}{ Ket. } \\
\hline Butir 1 & 0,665 & 0,3 & Valid \\
\hline Butir 2 & 0,704 & 0,3 & Valid \\
\hline Butir 3 & 0,599 & 0,3 & Valid \\
\hline Butir 4 & 0,66 & 0,3 & Valid \\
\hline Butir 5 & 0,61 & 0,3 & Valid \\
\hline Butir 6 & 0,696 & 0,3 & Valid \\
\hline Butir 7 & 0,556 & 0,3 & Valid \\
\hline Butir 8 & 0,574 & 0,3 & Valid \\
\hline Butir 9 & 0,646 & 0,3 & Valid \\
\hline Butir 10 & 0,562 & 0,3 & Valid \\
\hline Butir 11 & 0,419 & 0,3 & Valid \\
\hline Butir 12 & 0,578 & 0,3 & Valid \\
\hline Butir 13 & 0,655 & 0,3 & Valid \\
\hline Butir 14 & 0,586 & 0,3 & Valid \\
\hline
\end{tabular}

\section{Uji Reliabilitas}

Uji Reliabilitas menunjuk pada satu pengertian bahwa sesuatu instrument cukup dapat di percaya untuk digunakan sebagai alat pengumpul data. Butir kuesioner dikatakan reliable atau handal apabila jawaban seseorang terhadap kuesioner adalah konsisten. Dalam penelitian ini untuk menentukan kuesioner reliable atau tidak reliable menggunakan alpha cronbach. Kuesioner reliabel jika alpha cronbach > 0,06 dan tidak reliabel jika sama dengan atau dibawah 0,06 (Sunyoto, 2013: 141). 
Tabel 5. Hasil Uji Reliabilitas

\begin{tabular}{|l|l|l|}
\hline \multicolumn{1}{|c|}{ Variabel } & Alpha Cronbach & Ket. \\
\hline Kemandirian Belajar & 0,754 & Reliabel \\
\hline Kompetensi Dosen & 0,751 & Reliabel \\
\hline Motivasi Belajar & 0,750 & Reliabel \\
\hline
\end{tabular}

\section{Analisis Korelasi}

Korelasi digunakan untuk mengetahui hubungan antar variabel (Silalahi, 2012:

423).

Tabel 6. Correlations

\begin{tabular}{|l|l|r|r|r|}
\hline \multicolumn{2}{|l|}{} & Y & X1 & \multicolumn{2}{|c|}{ X2 } \\
\hline \multirow{4}{*}{ Y } & Pearson Correlation & 1 &, $841^{* *}$ &, $603^{* *}$ \\
\cline { 2 - 5 } & Sig. (2-tailed) & 135 &, 000 &, 000 \\
\cline { 2 - 5 } & N &, $841^{* *}$ & 135 & 135 \\
\hline \multirow{3}{*}{ X1 } & Pearson Correlation &, 000 & 1 &, $602^{* *}$ \\
\cline { 2 - 5 } & Sig. (2-tailed) & 135 & 135 &, 000 \\
\cline { 2 - 5 } & N &, $603^{* *}$ &, $602^{* *}$ & 135 \\
\hline \multirow{2}{*}{ X2 } & Pearson Correlation &, 000 &, 000 & 1 \\
\cline { 2 - 5 } & Sig. (2-tailed) & 135 & 135 \\
\cline { 2 - 5 } & N & & & 135 \\
\hline
\end{tabular}

**. Correlation is significant at the 0.01 level (2-tailed).

Tabel 7. Model Summary

\begin{tabular}{|l|l|r|r|r|}
\hline Model & $\mathrm{R}$ & \multicolumn{1}{|c|}{ R Square } & Adjusted R Square & Std. Error of the Estimate \\
\hline 1 &, $850^{\mathrm{a}}$ &, 722 &, 718 & 2,41026 \\
\hline
\end{tabular}

a. Predictors: (Constant), X2, X1

Hasil SPSS menunjukkan bahwa korelasi

Analisis regresi ganda adalah satu secara parsial antara X1 dengan $\mathrm{Y}$ sebesar 0,841 dan X2 dengan Y sebesar 0,603. Korelasi secara simultan antara X1 dan X2 dengan Y sebesar 0,850 teknik statistik yang dapat digunakan untuk menganalisa hubungan antara satu variabel dependen tunggal dan beberapa variabel - variabel independen (Silalahi, 2012: 430).

\section{Analisis Regresi Ganda}

Tabel 8. Coefficients ${ }^{\mathrm{a}}$

\begin{tabular}{|c|c|c|c|c|c|c|}
\hline \multirow{2}{*}{\multicolumn{2}{|c|}{ Model }} & \multicolumn{2}{|c|}{ Unstandardized Coefficients } & \multirow{2}{*}{$\begin{array}{c}\text { Standardized Coefficients } \\
\text { Beta }\end{array}$} & \multirow[b]{2}{*}{$\mathrm{t}$} & \multirow[b]{2}{*}{ Sig. } \\
\hline & & $\mathrm{B}$ & Std. Error & & & \\
\hline 1 & (Constant & ,930 & 2,330 & & ,399 & ,690 \\
\hline & $\mathrm{X} 1$ & 607 &, 046 & ,750 & 13,063 & ,000 \\
\hline & $\mathrm{X} 2$ & 107 &, 041 &, 151 & 2,636 & ,009 \\
\hline
\end{tabular}

a. Dependent Variable: Y 
Hasil SPSS menunjukkan bahwa penelitian ini menghasilkan model regresi $\mathrm{Y}=0,930+0,607 \mathrm{X} 1+0,107 \mathrm{X} 2$.

\section{Uji t}

Uji $\mathrm{t}$ digunakan untuk mengetahui ada tidaknya hubungan atau pengaruh yang berarti signifikan antara variable independen secara parsial terhadap variabel dependen (Sunyoto, 2013: 135). Secara parsial pengaruh X1 terhadap Y memiliki nilai $\mathrm{t}$ hitung sebesar 13,063 dengan nilai signifikan sebesar 0,00 dan nilai t hitung untuk variabel X2 terhadap Y sebesar 2,636 dengan nilai signifikan sebesar 0,00 .

Tabel 9. ANOVA ${ }^{\mathrm{a}}$

\begin{tabular}{|l|l|r|r|r|r|c|}
\hline \multicolumn{2}{|l|}{ Model } & Sum of Squares & df & Mean Square & F & Sig. \\
\hline \multirow{3}{*}{1} & Regression & 1994,204 & 2 & 997,102 & 171,638 &, $000^{\mathrm{b}}$ \\
\cline { 2 - 7 } & Residual & 766,833 & 132 & 5,809 & & \\
\cline { 2 - 7 } & Total & 2761,037 & 134 & & & \\
\hline
\end{tabular}

a. Dependent Variable: Y

b. Predictors: (Constant), X2, X1

Uji F

Uji $\mathrm{F}$ dilakukan untuk mengetahui pengaruh antara variabel independen terhadap variabel dependen secara bersama-sama (Sunyoto, 2013: 137). Secara Simultan nilai $F$ hitung sebesar 171,638 dengan nilai signifikan sebesar 0,00 artinya bahwa secara bersama-sama variabel X1 dan X2 memiliki Pengaruh yang signifikan terhadap variabel $\mathrm{Y}$.

\section{PEMBAHASAN}

\section{Pengaruh Variabel X1 terhadap Y}

Secara parsial variabel X1 memiliki hubungan yang sangat kuat terhadap variabel $\mathrm{Y}$ hal ini dibuktikan dengan hasil SPSS yang menunjukkan bahwa nilai korelasinya sebesar 0,841 dengan tingkat signifikan sebesar $0,00<0,05$. Nilai korelasi bertanda positif menunjukkan bahwa semakin tinggi kemandirian belajar maka akan semakin tinggi motivasi belajar mahasiswa dan sebaliknya.

1. Jika $\mathrm{t}$ hitung $\geq \mathrm{t}$ tabel, maka $\mathrm{H} 0$ ditolak dan Ha diterima, artinya terdapat pengaruh yang berarti antara Variabel X1 terhadap Y

2. Jika $\mathrm{t}$ hitung $<\mathrm{t}$ tabel, maka $\mathrm{H} 0$ diterima dan Ha ditolak, artinya tidak terdapat pengaruh yang berarti antara Variabel X1 terhadap Y

untuk variabel $\mathrm{X} 1$ nilai $\mathrm{t}$ hitung sebesar 13,063 > t tabel 0.195 maka H0 ditolak dan Ha diterima, artinya terdapat pengaruh yang signifikan antara variabel $\mathrm{X} 1$ terhadap variabel $\mathrm{Y}$. Hasil Penelitian ini sejalan dengan penelitian Abdul Haris yang menyatakan terdapat pengaruh yang positif dan signifikan antara motivasi belajar dengan kemandirian belajara siswa.

\section{Pengaruh Variabel X2 terhadap Y}

Secara parsial variabel X2 memiliki hubungan yang kuat terhadap variabel $Y$ hal ini dibuktikan dengan hasil SPSS yang menunjukkan bahwa nilai korelasinya sebesar 0,603 dengan tingkat signifikan sebesar $0,00<0,05$. Nilai korelasi bertanda positif menunjukkan bahwa semakin tinggi kompetensi dosen maka akan semakin tinggi motivasi belajar mahasiswa dan sebaliknya

1. Jika $\mathrm{t}$ hitung $\geq \mathrm{t}$ tabel, maka $\mathrm{HO}$ ditolak dan Ha diterima, artinya terdapat hubungan yang berarti antara Variabel X2 terhadap Y

2. Jika $\mathrm{t}$ hitung $<\mathrm{t}$ tabel, maka $\mathrm{H} 0$ diterima dan Ha ditolak, artinya tidak 
terdapat hubungan yang berarti antara Variabel X2 terhadap Y

untuk variabel $\mathrm{X} 1$ nilai $\mathrm{t}$ hitung sebesar 2,636 > t tabel 0.195 maka H0 ditolak dan Ha diterima, artinya terdapat pengaruh yang signifikan antara variabel $\mathrm{X} 2$ terhadap variabel Y. Hasil Penelitian ini sejalan dengan penelitian arisman dkk dan penelitian sudaryono yang menyatakan Terdapat pengaruh yang signifikan antara variabel kompetensi guru terhadap motivasi belajar siswa.

\section{Pengaruh Variabel X1 dan X2 terhadap Y}

Hubungan variabel $\mathrm{X} 1 \mathrm{dn} \quad \mathrm{X} 2$ terhadap Y sebesar 0,850 artinya variabel $\mathrm{X} 1$ dan X2 secara bersama-sama memiliki hubungan yang Sangat kuat dan signifikan terhadap variabel Y. Nilai Determinasi sebesar $0,722 \times 100 \%=72,2 \%$ artinya bahwa Variabel X1 dan X2 secara bersama-sama mempengaruhi variabel $\mathrm{Y}$ sebesar $72,2 \%$ dan sisanya seberas $27,8 \%$ dipengaruhi oleh variabel lain selain variabel X1 dan X2.

1. Jika $F$ hitung $\geq F$ tabel, maka H0 ditolak dan $\mathrm{Ha}$ diterima, artinya terdapat pengaruh yang berarti antara Variabel X terhadap Y

2. Jika $\mathrm{F}$ hitung < F tabel, maka H0 diterima dan Ha ditolak, artinya tidak terdapat pengaruh yang berarti antara Variabel X terhadap Y

Nilai F hitung sebesar 171,638 > F tabel 3.09 maka H0 ditolak dan Ha diterima artinya bahwa secara bersama-sama variabel X1 dan X2 memiliki Pengaruh yang signifikan terhadap variabel $\mathrm{Y}$.

Model regresi $\mathrm{Y}=0,930+0,607 \mathrm{X} 1+$ $0,107 \mathrm{X} 2$ artinya bahwa:

1. Jika nilai $X 1$ dan $X 2$ tetap maka nilai $Y$ sebesar 0,930

2. Jika nilai $X 2$ dan konstanta tetap dan nilai $\mathrm{X} 1$ naik maka nilai $\mathrm{Y}$ juga naik sebesar 0,607 dan sebaliknya jika nilai
$\mathrm{X} 1$ turun maka nilai $\mathrm{Y}$ juga turun sebesar 0,607

nilai X1 dan konstanta tetap dan nilai X2 naik maka nilai $\mathrm{Y}$ juga naik sebesar 0,107 dan sebaliknya jika nilai X2 turun maka nilai $Y$.

\section{KESIMPULAN DAN SARAN \\ Kesimpulan}

1. Variabel kemandirian belajar secara parsial memiliki pengaruh positif dan signifikan terhadap variabel motivasi belajar mahasiswa.

2. Variabel kompetensi dosen secara parsial memiliki pengaruh positif dan signifikan terhadap variabel motivasi belajar mahasiswa.

3. Variabel kemadirian belajar dan kompetensi dosen secara simultan memiliki pengaruh yang signifikan terhadap variabel motivasi belajar mahasiswa.

\section{Saran}

1. Untuk penelitian selanjutnya dapat ditambahkan variabel-variabel lain untuk mengetahui faktor yang mempengaruhi motivasi belajar mahasiswa

2. Mengingat karakteristik dan demografis indonesia yang beragam penelitian dapat di lakukan di daerah lainnya . 


\section{REFERENSI}

Arisman, dkk. (2018). Pengaruh Kompetensi Kepribadian Guru Terhadap Motivasi Belajar Peserta Didik Mtsn 2 Bone Kabupaten Bone: Jurnal Diskursus Islam 6(3) 418-443

Drost. (1995). Menjadi Pribadi Dewasa dan Mandiri. Yogyakarta: Kanisius

Hamalik, Oemar. 2002. Pendidikan guru berdasarkan pendekatan kompetensi. Jakarta: PT. Bumi Aksara

Haris, Abdel (2017) Motivasi Belajar Pengaruhnya terhadap Kemandirian Belajar Mahasiswa Melalui Model ARCS serta: Nuansa ; Jurnal Ilmiah Pendidikan. 6(1) 1-20

https://mediaindonesia.com/humaniora /321039/dampak-pandemikualitas-pendidikan-alamipenurunan

Miarso, Y. (2005). Menyamai Benih Teknologi Pendidikan. Jakarta: PustekkomKencana.

Sardiman A.M. (2014). Interaksi dan Motivasi Belajar Mengajar. Jakarta:Grafindo

Silalahi, Ulber. 2012. Metode Penelitian Sosial. Refika Aditama. Bandung.

Siregar, A. R. (2006). Motivasi Berprestasi Mahasiswa Ditinjau dari Pola Asuh. Jakarta:
Gramedia Pustaka.

Sudaryono, dkk (2019) Pengaruh Persepsi Kompetensi Dasar Dosen Terhadap Motivasi Belajar Mahasiswa : Jurnal Pendidikan, Akuntansi dan Keuangan Universitas Banten Jaya. 2(1) 31-46.

Sugiyono. 2009. Metode Penelitian Pendidikan (Pendekatan Kuantitatif, Kualitatif, dan R\&D). Bandung: Alfabeta.

Sugiyono. 2017. Metode Penelitian Pendidikan Pendekatan Kuantitatif, Kualitatif, dan $R \& D$. Bandung: Alfabeta.

Suharsaputra, Uhar. 2012. Metode penelitian. Bandung. PT Refika Aditama.

Sunyoto, Danang. 2013. Teori, Kuesioner dan Analisis Data. Untuk Pemasaran dan Perilaku Konsumen. Graha Ilmu. Yogyakarta.

Undang-Undang No.14 Tahun 2005. Guru dan Dosen. Yogyakarta: Pustaka Pelajar Offset.

Undang-Undang No.20 Tahun 2003. Tentang Sistem Pendidikan Nasional Beserta Penjelasannya.

Wijaya, Cece dan Rusyan, A. Tabrani. 1994. Kemampuan Dasar Guru Dalam Proses BelajarMengajar. Bandung: Remaja Rosdakarya. 